International Journal of Business Management and Economic Review

Vol. 4, No. 06; 2021

ISSN: 2581-4664

\title{
MULTINATIONAL ENTERPRISES AND THE SUSTAINABLE DEVELOPMENT GOALS IN NIGERIA
}

\author{
Apreala, Solomon Ebiladei \\ University of Nigeria, Enugu Campus \\ Rev. Fr. Dr. Anthony Aniagbaoso Igwe \\ University of Nigeria, Enugu Campus \\ http://doi.org/10.35409/IJBMER.2021.3322
}

\begin{abstract}
The qualitative impact and influence of multinational corporations (MNCs) on society, as defined by the United Nations (UN) 2030 agenda, as well as their contribution to Nigeria's attainment of the Sustainable Development Goals (SDGs), were studied (SDGs). Additionally, it establishes the framework for a "new corporate social responsibility" in terms of the corporate Nigerian business sector's increasing commitment to sustainability. This research also examines the nature and function of multinational corporations, contrasting non-state elements, responsibilities in broader social settings, and state obligations in achieving the SDGs. Additionally, this study suggests practical measures for achieving the SDGs in Nigeria, including progressive roles for both the state and multinational corporations (MNCs), with the goal of complementing states' responsibilities for providing public goods and social services that will assist Nigeria and Africa in achieving the SDGs.
\end{abstract}

Keyword: Multinational Enterprises, Sustainable Development Goals, Corporate Social Responsibility, Environmental Sustainability.

\section{INTRODUCTION}

Nigeria is no longer regarded as one of the countries with poor long-term development prospects in global assessments. The country has a history of failing to meet $\mathrm{UN}$ objectives, raising fears that it may fall behind on Africa's new Agenda 2030 Sustainable Development Goals.

The purpose of this article is to discuss multinational companies and Nigeria's long-term development objectives. The 2030 Agenda for Sustainable Development was approved by the United Nations General Assembly in 2015, creating a new 15-year framework for achieving the SDGs and tackling global issues such as poverty, inequality, climate change, environmental degradation, peace, and justice (SDGs). They serve as a road map for a more equitable and sustainable future for everyone. The Sustainable Development Goals (SDGs) were inspired by the Stockholm Declaration of 1972, the Brundtland Report, the Rio Declaration of 1992, and the Millennium Development Goals of 2000. (MDGs). The United Nations 2030 Agenda for Sustainable Development is a worldwide accord that recognises the interconnected nature of global issues and has been supported by world leaders. There are a total of seventeen goals, 169 indivisible targets, and 230 indicators. The concept of sustainable development, as expanded by the SDGs, has exploded into a global phenomenon, serving as both an ideal to strive for and a jumping-off point for any serious discussion of development. Sustainability has gained traction in 


\section{International Journal of Business Management and Economic Review}

Vol. 4, No. 06; 2021

ISSN: 2581-4664

the business world, and it has evolved into a catch-all term for a variety of actions and activities relating to the environment, profitability, and corporate social responsibility that multinational corporations or enterprises (MNCs) engage in (CSR).

While there is an increasing understanding of the significance of sustainability, most of what businesses undertake to accomplish it is still done on a more or less voluntary basis, since there are often no required local or international regulations to comply. In other words, while almost everyone, including multinational corporations, recognises the need to work toward the realisation of the SDGs, no concrete, robust, or comprehensive enforcement framework has yet to be established. This challenge is exacerbated within the continent of Africa which has not only missed previously set global goals for development but also generally has very weak (if not poorly enforced) or sometimes non-existent regulatory framework for corporate responsibility and accountability. With the recent recognition of the need to redistribute obligations between government as well as non actors in order to counter MNCs' powerful influence, it appears that the question of whether non-state actors, including MNCs, can be assigned new or additional responsibilities in addition to their current roles in order to assist Nigerian governments in achieving the SDGs is relevant. Is it desirable for states to impose further constraints on MNCs beyond the narrow pursuit of profit towards the attainment of the SDGs in Nigeria?

\section{THE INFLUENCE OF MULTINATIONAL CORPORATIONS ON GOVERNMENT}

MNCs are companies that engage in foreign direct investments. They have a residence in one nation, yet they operate and live under the rules of many others. MNCs have two distinguishing characteristics: first, their operations span several countries, and second, they account for the majority of foreign direct investment (Dan-Jumbo \& Akpan, 2018). As a result, a multinational company is one that participates in FDI and owns or controls value-adding operations in several countries. Multinationals' activity increased dramatically from 1994 to 2006. In 1970, there were only 7,000 MNCs (Kolodnier 1994:2), but by 1994, there were 63,000 multinational parent companies managing over 690,000 international affiliates. This number has grown to nearly 780,000 foreign affiliates in 2006 by the year 2000 (UNCTAD, 2000:37).

MNCs have the ability to influence development policy due to their sheer size and economic power. Because of the perceived advantages, elected governments are increasingly making political and economic choices to create favourable settings for MNCs' investment and marketing requirements. As a result, businesses may occasionally influence domestic policy results in host developing nations by threatening to relocate employment. This often raises concerns about whether MNCs may successfully hinder sustainable development by bypassing local environmental regulations because of their corporate strength. Furthermore, the fear of companies moving employment abroad, as well as the assessment of the economic impact, may affect the degree to which emerging nations impose environmental restrictions on multinational corporations (Porter, 1999).

\section{An Overview of The Nigerian Economy}

Nigeria has the biggest economy in Sub-Saharan Africa, with oil being the main source of foreign currency and income for the government. The banking industry was effectively recapitalized and 


\section{International Journal of Business Management and Economic Review}

Vol. 4, No. 06; 2021

ISSN: 2581-4664

rules were tightened after the global financial crisis of 2008-09. Agriculture, telecommunications, and services have all played a role in Nigeria's economic growth since then. In Nigeria, where more than 62 percent of the 180 million people live in poverty, diversification and rapid economic development have failed to reduce poverty. Nigeria's oil-rich economy has been harmed by a lack of power, infrastructure, legislative reform delays, an insufficient property registration system, protectionist trade policies, inconsistent legal frameworks, a slow and ineffective judicial system, untrustworthy dispute resolution methodologies, insecurity, and widespread corruption, despite its strong foundations. With the exception of a short uptick in 2017, Nigeria's oil output has been declining year after year since 2012. Regulations and security concerns have hindered new oil and gas investment, and Nigeria's oil output has been falling year after year since 2012.

In March 2015, President BUHARI entered office, appointing a technocratic economic cabinet and promising to diversify the economy away from oil while tightening budgetary restrictions. On the other side, his policies have mostly been protectionist, favouring domestic producers over patrons. President BUHARI ran on an anti-corruption platform and has made significant progress, including the creation of a Treasury Single Account, which allows the government to better regulate its reserves, as well as a more unbiased administration salary and personnel system, which eliminates duplication and "ghost" employees. Furthermore, in the areas of transportation, agriculture, and energy, the government is interested in public-private partnerships.

Nigeria experienced a recession in 2016 due to decreasing oil prices and output, which was worsened by terrorist assaults on Niger Delta oil and gas facilities and unfavourable economic policies like as currency restrictions. As oil prices recovered and production stabilised, GDP growth increased to a positive level in 2017.

\section{Sustainable Development Goals}

The Sustainable Development Goals (SDGs) are a set of 17 well-articulated global goals developed by the United Nations in collaboration with member country governments and international organisations with the goal of achieving global sustainability by 2030. Additionally, they contain 169 quantitative and qualitative goals addressing social, economic, and environmental issues. According to a resolution adopted by the United Nations General Assembly titled "Transforming our World: The 2030 Agenda for Sustainable Development," "this agenda is a blueprint for people, planet, and prosperity" (United Nations, 2015). Additionally, it aims to promote world peace within a more expansive framework of liberty. This strategy will be implemented in collaboration with all countries and stakeholders. The Sustainable Development Goals (SDGs) of the United Nations have already had an effect on international policymakers and inspired academic interest in development and environmental studies (see. g. Oldekopetal., 2016, and the thematic issues of Current Opinion in Environmental Sustainability, February2017, and International Environmental Agreements, June 2016). The seventeen main objectives listed below address a wide variety of social and economic development issues:

\section{Poverty-Free}

2. There will be no hunger. 
International Journal of Business Management and Economic Review

Vol. 4, No. 06; 2021

ISSN: 2581-4664

3. Excellent physical and mental health

4. Superior Quality Education

5. Equality of Women and Men

6. Water that is safe to drink and sanitation

7. Energy that is both affordable and clean

8. Work that is decent and economic growth

9. Infrastructure, Industry, and Innovation

10. Inequalities Have Been Reduced.

11. Cities and Communication that are Sustainable

12. Consumption and Production with Integrity

13. Action on Climate Change

14. Submerged life

15. Terrestrial life

16. Justice, Peace, and Stable Institutions

17. Collaborations to accomplish objectives

3. MULTINATIONAL ENTERPRISES AND STATES' RESPONSIBILITIES FOR ATTAINING THE SDGS

Understanding the roles performed or capable of being played by businesses in achieving the SDGs requires an understanding of the nature and extent of firms' obligations or influence in society, particularly MNCs. To begin with, trying to come up with a universally accepted definition of MNCs may not be very helpful. The OECD Guidelines for Multinational Enterprises (the OECD Guidelines), which are an overarching cooperative agreement among adhering states outlining principles of globally acceptable corporate behaviour in the social and environmental spheres, concluded that precisely defining MNCs would be difficult and unnecessary for the OECD Guidelines. MNCs, on the other hand, are defined as businesses that operate across all sectors of the economy and are typically comprised of companies or other entities with operations in multiple countries that are so closely connected that they can coordinate their operations in a variety of ways, according to the guidelines.

"Today, the economically most powerful firms are multinational enterprises made up of connected companies that are regarded for most legal purposes as separate entities-even if, as is usually the case, the organisation as a whole is co-ordinated by a single management team," writes Paddy 


\section{International Journal of Business Management and Economic Review}

Vol. 4, No. 06; 2021

ISSN: 2581-4664

Ireland (2018). The fundamental notion of direct or indirect shareholder control is unaffected by the increasing complexity of emerging structures, which may include subsidiaries, cross-holdings, joint ventures, and other arrangements."

Even if a precise description is not possible, understanding what MNCs are not is beneficial. MNCs are not a legally defined or recognised entity. According to Janet Dine, MNCs are commercial conglomerates comprised of complicated structures of distinct companies with a diverse array of interrelationships, and they serve as moral deflection devices designed to create ethical loopholes.

Legal authority over the MNC as a whole and its transnational operations is distributed among the different nations in which its individual group members conduct business. MNCs are composed of legally distinct companies that must adhere to the laws and regulations of the nation in which they are headquartered.

MNCs have basically become globalization's driving force. The shareholder primacy model's supremacy has aided the development of shareholder value MNCs across the globe, which has not only contributed to global income and wealth inequality but also fused these corporate groupings into a new financial aristocracy. This has also aided the "financialization" of the global economy, as Gerald Epstein put it. The importance of the following broad definition of MNCs' function and nature is a proof of the enormous power and worldwide influence MNCs have grown to have. MNCs are so strong that they have an effect not just on national legislation, but also on the degree to which they are regulated under international law. Robert McCorquodale uses the example of BHP, an Australian corporation with such clout over the government of Papua New Guinea that the government passed laws largely drafted by BHP to shield the company from legal challenges regarding its operations there, despite the fact that those operations had a profound negative impact on the country's own citizens (2009).

Due to the enormous power and influence of the aforementioned MNCs, as well as their complex nature, regulating and monitoring the validity of their sustainability or CSR reports has proven difficult. Due to this lax regulatory environment, there are many examples of multinational companies (MNCs) abusing their power and violating human rights, as well as other detrimental repercussions for society. The 1984 Bhopal disaster, which killed tens of thousands of people when a toxic gas cloud erupted from a pesticide factory in Bhopal, India (owned by an Indian affiliate of the US-based Union Carbide Corporation, which is now a part of Dow Chemical); and (ii) Nike and other apparel and footwear companies accept terrible labour conditions in their facilities ("sweatshops"). (iii) Unocal's alleged involvement in the Burmese military government's human rights abuses during the building of a local gas pipeline; (iv) a local garbage management firm entrusted with the rubbish by Trafigura, a global petroleum trading corporation, dumped hazardous material in Abidjan, Ivory Coast, in 2006; and (v) the negative consequences of nearly 20 years of operations.

However, the narrative of MNCs' involvement in society does not have to be all doom and gloom (Ivwurie, \& Akpan, 2021). "No institution other than the state dominates our public discourse and our private lives," as Lawrence Mitchell put it. Almost everything we consume is made by 


\section{International Journal of Business Management and Economic Review}

Vol. 4, No. 06; 2021

ISSN: 2581-4664

corporations. Almost every waking minute of our life is consumed with their advertising and goods. They provide us with employment and, in certain cases, a sense of self-identity. They help to identify neighbourhoods and enrich both our popular and serious cultures. They teach us how to invest in order to pay for our children's college education and retirement. They finance our research... Businesses' influence on our lives indicates that they have a significant effect on our lives, whether purposefully or unintentionally."

The above seems to emphasise not just the significant role MNCs have played, but also the important role MNCs may play in the quest or fulfilment of the SDGs in Nigeria and Africa as a whole. Notwithstanding, the increase in the powers of the MNCs as a result of the globalized and financialized world economies also confirms that for MNCs to put their enormous powers and influence to better use in the actualization of the SDGs, improved legal, regulatory and enforcement framework will have to be designed by host states for business operations. Such improved legal and enforcement system is suggested among other recommendations in section 3.0. However, before making such recommendations, it is necessary to define the roles and responsibilities of state actors in order to ensure that, even if MNCs must use their global influence to support the achievement of sustainability goals, they should not be given new or additional responsibilities that would imply that they are taking over the primary responsibilities of states in providing public goods.

According to research, the worldwide growth of corporate power contrasts with the decreasing influence of governmental players, especially in Africa. Regardless of MNC influence, and despite states' diminishing powers and weakened sovereignty, MNCs should maintain a primary focus on business, as states' constitutional, fundamental, and internationally recognised obligations to provide public goods and social services as envisioned in the SDGs continue to be their primary responsibility. State accountability is a notion based in customary international law and reinforced by the idea of state duty to protect human rights in international law. Furthermore, it is now generally accepted that governments, as responsible to their electorates, should make public policy choices, while managers, as accountable to their shareholders, should run their businesses, and corporations should refrain from attempting to fulfil government functions. "We reaffirm the importance of the Universal Declaration of Human Rights, as well as other international instruments relating to human rights and international law," world leaders said in the United Nations 2030 Agenda, adding, "We reaffirm the importance of the Universal Declaration of Human Rights, as well as other international instruments relating to human rights and international law." All governments are responsible for safeguarding, preserving, and advancing human rights and basic freedoms, regardless of race, colour, gender, sexual orientation, language, religion, political or other views, national or social origin, property, birth, disability, or other status.

Furthermore, the constitution requires all government organs and authorities, as well as anyone exercising legislative, executive, or judicial authority, to ensure that all citizens have equal and adequate educational opportunities at all levels, to protect Nigeria's water, air, land, forest, and wildlife, and to safeguard and improve the environment. Despite concerns that such constitutional requirements are excessive, Nigeria and all other African countries unanimously adopted the 2030 Agenda for Sustainable Development, reiterating their commitment to the Sustainable 


\section{International Journal of Business Management and Economic Review}

Vol. 4, No. 06; 2021

ISSN: 2581-4664

Development Goals. By adopting the 2030 Agenda, all countries recognised their shared responsibility for reviving and strengthening global cooperation in order to eradicate poverty, enhance health and education, and decrease inequality. The Universal Declaration of Economic, Social, and Cultural Rights (ICESCR), which Nigeria and a large number of other African countries signed and ratified on July 29, 1993, is also a critical component of the 2030 Agenda. Both the SDGs and the ICESCR aim to coordinate efforts toward poverty eradication and ensuring that no one is left behind. According to Article 2(1) of the ICESCR, nations must take all reasonable steps to gradually realise the covenant's rights, both individually and via international aid and collaboration. Governments must not only adhere to their ICESCR obligations; they will also be better equipped to achieve the SDGs if they do so sustainably and in accordance with the human rights of current and future generations, as the United Nations Committee on Economic, Social, and Cultural Rights has stated (CESCR). Despite its lack of legal power, the UN's Protect, Respect, and Remedy Framework is arguably the most effective international framework for highlighting state accountability and responsibility (UNGPs). While the UNGPs charge businesses (particularly multinational corporations) with protecting human rights, Pillar I of the framework places the main obligation, duty, and responsibility for long-term preservation of rights on governments. The UNGPs are worth noting in this article because, despite their non-committal and voluntarist stance, they have become an internationally necessary framework in any discussion of corporate human rights abuses. Despite the business community's enormous power, influence, and control, the article contends that governments, including those in Africa, cannot afford to abdicate their responsibilities to MNCs in light of the preceding clear demonstration of state responsibility for ensuring the achievement of the SDGs and targets. What measures may African countries take, using the CSR framework, to impose additional but long-term responsibilities on multinational corporations in order to accomplish the SDGs? Some practical solutions to this issue are listed below.

\subsection{Specific State Measures Towards Realizing The Sdgs}

Two major points are gleaned from the foregoing discussions. One is that MNCs have so much grown in powers and influence in our highly globalized and financialized societies that intentionally or not, they affect virtually everything in the human society and a re-assignment of new roles (as additional corporate social responsibilities) on the misdesirable, if not long overdue. The second major point is that, regardless of whether state powers have waned to the point where multinational corporations (MNCs) dictate policy direction to states and governments, states and governments cannot afford to ignore their constitutionally recognised and internationally mandatory commitments to protect citizens' civil, political, economic, social, as well as cultural rights, as enshrined in the United Nations Charter. If no one will be truly left behind in poverty and the excesses of MNCs must be curbed, including rampant deprivation of citizens' socioeconomic, cultural and other rights, states cannot simply afford to leave the shareholder-primacymodel-strengthened MNCs to their whims and caprices in their otherwise narrow pursuit of profit. The need of fostering partnerships between state and non-state entities has never been greater. As a result, the following suggestions seem to be appropriate:

\section{NEW CSR ROLES FOR NIGERIA}

The twin ideas of sustainable development and corporate social responsibility, as mentioned 


\section{International Journal of Business Management and Economic Review}

Vol. 4, No. 06; 2021

ISSN: 2581-4664

previously 2, must be recognised for what they are in Nigeria. Sustainability is not just about MNCs dishing out CSR or sustainability reports without any one testing, monitoring, or confirming the accuracies of information disclosed and reported. CSR, it must never be forgotten, goes beyond corporate philanthropy, tokenism, or community development initiatives such as supplying piped water, hospitals, and schools with surplus company earnings, or offering scholarships. CSR began as a countervailing authority used by the government to curb the raw use of corporate power in the public interest during corporate governance reforms. CSR may be a formidable regulatory weapon in the hands of an educated government that is committed to preserving its constitutionally enshrined and internationally recognised duty to preserve the civil, political, economic, social, and cultural rights of all persons within its jurisdiction. All African governments must view the pursuit of CSR initiatives aimed at realising the SDGs within the business community as a tool for persuading multinational corporations to respect and not damage broader social settings. If no one is to be left behind, relevant changes to corporation legal systems in different jurisdictions that otherwise promote CSR implementation as a concept of merely giving back to society by MNCs should be reviewed. Provisions in many African states' corporate law system with which the identified shareholder primacy model has been entrenched should be amended to tilt towards corporate stakeholder with more friendly provisions. Awakening from any slumber of corporate influence and bondage, African governments need to countervail the enormous powers and influence of MNCs and adopt policies taking CSR and the realization of the SDGs as a continuous process of safeguarding the interests and rights of all corporate stakeholders in the society, including the host communities, the employees, the customers and consumers, creditors, government agencies and so on.

\subsection{New Csr Roles For The Mncs}

MNCs also need to improve on their CSR conceptualization and their business pursuit of sustainability. Businesses do not operate in a vacuum within society. Without widespread recognition, constant interaction, and concession from the state and society-society comprising creditors, employees, customers, host and impacted communities, and the natural environmentbusinesses cannot survive, operate, or function, let alone achieve economic gains, growth, or development. Along with corporate philanthropy, MNCs must recognise the importance of CSR as a proactive corporate governance tool for controlling the social, economic, and environmental risks connected with their activities. MNCs will be able to conduct efficient and ongoing due diligence activities in accordance with effective internal CSR policies, enabling them to detect and evaluate any negative effects of company operations on corporate stakeholder rights, as well as assess potential preventive or mitigating actions. The scope of due diligence may vary from business to business, transaction to transaction and depending on circumstances. This way, MNCs will be putting their enormous powers, influence and control in the society to good and effective use. They will, accordingly, be taking steps and undertaking activities supportive of the government towards the realization of the SDGs rather than causing harm and jeopardizing such realization. To be clear, engaging in such due diligence is not corporate waste but an effective strategy of not only maintaining the MNCs social license to operate within the communities but also sustainably complementing the state duty and responsibility to achieving the SDGs. This recommendation and its adoption are also compliant with the UNGPs framework as the leading globally acceptable template for redistribution of responsibilities between the state and businesses. 
International Journal of Business Management and Economic Review

Vol. 4, No. 06; 2021

ISSN: 2581-4664

\section{INTEGRATED REGIONAL RESPONSE IN AFRICA}

As the Brundtland Report and the current United Nations 2030 Agenda for Sustainable Development show, many global problems are linked and transnational in character.

Furthermore, despite of CSR policies and ongoing due diligence procedures by MNCs, violation of rights, particularly those that transcend countries owing to the complex structure of the MNCs, will almost certainly persist. Therefore, the steps taken by African states at their respective domestic levels towards improving corporate responsibility of MNCs will have certain limitations. First, where the domestic CSR policies in one state are considered too stringent, MNCs are well financed and financialized to decide moving to jurisdictions with weaker regulatory framework. Second, such domestic steps taken by states may not address corporate irresponsibility of MNCs which are cross-border in nature. Although it is recognized that no law restricts states from taking steps with exterritorial application to address such cross-border abuses by MNCs, such steps run the risk of inter-state friction. African leaders established the "Agenda 2063" framework in 2015, which envisions a thriving Africa based on fair growth and long-term development despite impending difficulties. Additionally, it embodies Africa's vision of a continent in which freedom of movement of people, money, commodities, and services results in substantial gains in trade and investment between African nations. The African Continental Free Trade Area (AfCFTA), a key Agenda 2063 initiative of the African Union, seeks to help African countries in achieving the Sustainable Development Goals (SDGs). Because of the cross-border nature of the activities and the potential for MNC misuse, African nations should completely incorporate CSR implementation inside the AfCFTA framework to better regulate the exercise of raw corporate power by powerful MNCs at the AU's intergovernmental level. The ambit of this proposed recommendation has been argued elsewhere. To conclude, this proposal encourages African nations to mainstream successful CSR conceptualization and implementation frameworks within the continent's regional integration debate. This will involve the inclusion of a CSR implementation protocol in the AfCFTA agreement, as well as the periodic publishing of instructions for legal transposition into African nation's domestic company law systems. This creates a unified CSR policy framework for Africa and aligns the continent's wider sustainable development plan with the SDGs. The proposed framework will also address instances of jurisdictional arbitrage or MNCs forum shopping from one jurisdiction in Africa to another as may otherwise be believed with too stringent regulations. This recommendation also offer support in addressing the challenge of double standards of some MNCs with different CSR policy standards from one jurisdiction to the other. Adopting the foregoing strategies, the article submits that African states will better discharge their responsibilities, ensuring not only effective lifting of their citizens out of poverty and other social challenges but also giving themselves the chance of not being left behind in yet another global developmental target by 2030 .

\section{CONCLUSION}

The 2030 Agenda for Sustainable Development was incorporated by world leaders in 2015 to address worldwide issues such as poverty, inequality, climate change, and ecological pollution, as well as to create a new 15-year framework for attaining the Sustainable Development Goals. The SDGs were created to expand on previous development objectives, including the 1972 Stockholm Declaration, the 1992 Brundtland Report, the 1992 Rio Declaration, and the 2000 Millennium 


\section{International Journal of Business Management and Economic Review}

Vol. 4, No. 06; 2021

ISSN: 2581-4664

Development Goals. In order to improve Nigeria's chances of meeting the 2030 global development target and progressing toward the framework of African leaders' "Agenda 2063," which calls for a prosperous Africa built on inclusive growth and sustainable development, this article emphasised the importance of effective corporate social responsibility in achieving sustainable development. This article highlighted obstacles threatening the achievement of the SDGs in Nigeria and Africa as a whole by juxtaposing MNC and state roles in promoting sustainable development. The report highlighted, among other things, the decreasing economic resources at the disposal of many governments, as well as the deteriorating nations' ability to achieve the SDGs. This was contrasted with the enormous powers of highly financialized, shareholder-primacy-model-strengthened MNCs which can be leveraged to either jeopardize or complement state responsibilities in the course of advancing sustainability. Given the importance of fostering partnerships between state and non-state actors, the report concluded by recommending additional but integrated responsibilities for both states and MNCs, allowing Nigeria and the African continent to perform better in global audits of the 2030 long-term development agenda.

\section{REFERENCES}

Ango, N. A. (2012). Business Ethics and Practice in Multinational companies: Evidence from Nigeria.

Aworom Annang (2013). Multinational Corporations and Development in Nigeria. African Journal of Culture, Philosophy and Society 3(1),62-67.

Bernardine,H. J. (2003) in Onodugo (2012). Multinational Corporations and employment and labour conditions of developing countries: The Nigerian Experience. European Journal of Business and Social Sciences, 1(6), 67-76.

Dan-Jumbo, C. T., \& Akpan, E. E. (2018). The promises and perils of multinational corporations: The Nigerian experience. International Journal of Management Science and Business Administration, 4(3), 71-76.

Igwe C.N., Adebayo M.S., Olakanmi O.A., Ogbonna I.G., and Aina O.S. (2013), Promoting wealth and job creation in Nigeria-Review of the Role of Entrepreneurship. Journal of Sustainable Development Studies 3(1).

Ivwurie, E.A., \& Akpan, E. E. (2021). Strategic corporate social responsibility and sustainability of multinational corporations in Nigeria. Research Journal of Business and Management, 8 (2), 51-61

Janet Dine Companies, International Trade and Human Rights (Cambridge: Cambridge University Press, 2005) 43-48.

Jason Prno (2013) "An Analysis of Factors Leading to the Establishment of a Social Licence to Operate in the Mining Industry" 38 Resources Policy, 577-59

Lingelbach D., De la Viña L. and Asel P. (2005). What's Distinctive About Growth-Oriented Entrepreneurship in Developing Countries?

Nojeem Amodu (2020) "Corporate Social Responsibility and Economic Globalization: Mainstreaming Sustainable Development Goals into the AfCFTA Discourse" 47:1 Legal Issues of Economic Integration 71-104, 77.

OECD, OECD Guidelines for Multinational Enterprises (OECD Publishing, 2011) 17; available at http://dx.doi.org/10.1787/9789264115415-en accessed 24April 2020. 
Vol. 4, No. 06; 2021

ISSN: 2581-4664

Paddy Ireland (2018) "Making Sense of Contemporary Capitalism using Company Law" 33:3 Australian Journal of Corporate Law 379-401, footnote 75 and surrounding texts.

Oldekop, J. A., Fontana, L. B., Grugel, J., Roughton, N., Adu-Ampong, E. A., Bird, G. K., Dorgan, A., Vera Espinoza, M. A., Wallin, S., Hammett, D., Agbarakwe, E., Agrawal, A., Asylbekova, N., Azkoul, C., Bardsley, C., Bebbington, A. J., Carvalho, S., Chopra, D., Christopoulos, S., Crewe, E., Dop, M. C., Fischer, J., Gerretsen, D., Glennie, J., Gois, W., Gondwe, M., Harrison, L. A., Hujo, K., Keen, M., Laserna, R., Miggiano, L., Mistry, S., Morgan, R. J., Raftree, L. L., Rhind, D., Rodrigues, T., Roschnik, S., Senkubuge, F., Thornton, I., Trace, S., Ore, T., Valdés, R. M., Vira, B., Yeates, N., and Sutherland, W. J.(2016). 100 key research questions for the post2015 development agenda. Development Policy Review, 34(1), 55-82.

Onodugo Vincent.A (2012).Multinational corporations (MNCs) and employment and labour conditions of Developing Countries: The Nigerian Experience. European Journal of Business and Social Sciences, 1( 6), 67-76.

Osuagwu Godwin Onyebuchi and EzieObumneke (2013).International Journal of Academic Research in Business and Social Sciences 3(4).

Schaumburg-Müller H., Jeppesen S. \& Langevang T. (2010). Entrepreneurship Development in Africa. CBDS Working Paper Series Working Paper Nr. 12.

United Nations (2014). The road to dignity by 2030: Ending poverty, transforming all lives and protecting the planet. Synthesis report of the Secretary-General on the post-2015 sustainable development agenda. UN General Assembly, A/69/700, 4 December.

United Nations (2015). Resolution adopted by the General Assembly on 25 September 2015.A/RES/70/1. https://sustainabledevelopment.un.org/post2015/transformingourworld.

United Nations General Assembly Transforming our World: the 2030 Agenda for Sustainable Development resolution adopted by the General Assembly on 25 September 2015, UN Doc $\mathrm{A} / \mathrm{RES} / 70 / 1$.

World Bank (2015) Nigeria Country Profile: Enterprise Survey.

Appendixes I 
Table 1: Annual Time Series Data For Gdp And Foreign Direct Investment Into Nigeria 1970-2011.

\begin{tabular}{|c|c|c|c|c|}
\hline $\mathrm{S} / \mathrm{N}$ & YEAR & $\begin{array}{l}\text { Gross } \\
(\text { GDP) }\end{array}$ & Domestic Product & $\begin{array}{l}\text { Foreign Direct Invest. } \\
(\mathrm{FDI})\end{array}$ \\
\hline 1 & 1970 & & 5281.100 & 1003.200 \\
\hline 2 & 1971 & & 6650.900 & 1322.800 \\
\hline 3 & 1972 & & 7187.500 & 1571.100 \\
\hline 4 & 1973 & & 8630.500 & 1763.700 \\
\hline 5 & 1974 & & 18823.10 & 1812.100 \\
\hline 6 & 1975 & & 21475.20 & 2287.500 \\
\hline 7 & 1976 & & 26655.80 & 2339.000 \\
\hline 8 & 1977 & & 31520.30 & 2531.400 \\
\hline 9 & 1978 & & 34540.10 & 2863.200 \\
\hline 10 & 1979 & & 41974.70 & 3153.100 \\
\hline 11 & 1980 & & 49632.30 & 3620.100 \\
\hline 12 & 1981 & & 47619.70 & 3757.900 \\
\hline 13 & 1982 & & 49069.30 & 5382.800 \\
\hline 14 & 1983 & & 53107.40 & 5949.500 \\
\hline 15 & 1984 & & 59622.50 & 6418.300 \\
\hline 16 & 1985 & & 67908.60 & 6804.000 \\
\hline 17 & 1986 & & 69147.00 & 9313.600 \\
\hline 18 & 1987 & & 105222.8 & 9993.600 \\
\hline 19 & 1988 & & 139085.3 & 11339.20 \\
\hline 20 & 1989 & & 216797.5 & 10436.10 \\
\hline 21 & 1990 & & 267550.0 & 12243.50 \\
\hline 22 & 1991 & & 312139.7 & 20512.70 \\
\hline 23 & 1992 & & 532613.8 & 66787.00 \\
\hline 24 & 1993 & & 683869.8 & 70714.60 \\
\hline 25 & 1994 & & 899863.2 & 119391.6 \\
\hline 26 & 1995 & & 1933212. & 122600.9 \\
\hline 27 & 1996 & & 2702719. & 128331.9 \\
\hline 28 & 1997 & & 2801973. & 152410.9 \\
\hline 29 & 1998 & & 2708431. & 154190.4 \\
\hline 30 & 1999 & & 3194015. & 157508.6 \\
\hline 31 & 2000 & & 4582127. & 161441.6 \\
\hline 32 & 2001 & & 4725086 . & 166631.6 \\
\hline 33 & 2002 & & 6912381. & 178478.6 \\
\hline 34 & 2003 & & 8487032. & 249220.6 \\
\hline 35 & 2004 & & 11411067 & 324656.7 \\
\hline 36 & 2005 & & 14572239 & 481239.1 \\
\hline 37 & 2006 & & 18564595 & 552498.6 \\
\hline 38 & 2007 & & 20657318 & 387261.3 \\
\hline
\end{tabular}


International Journal of Business Management and Economic Review

Vol. 4, No. 06; 2021

ISSN: 2581-4664

\begin{tabular}{|c|c|c|c|}
\hline 39 & 2008 & 24296329 & 399841.9 \\
\hline 40 & 2009 & 24712670 & 441271.3 \\
\hline 41 & 2010 & $3.40 \mathrm{E}+10$ & 5234383. \\
\hline 42 & 2011 & $3.75 \mathrm{E}+10$ & 5673950. \\
\hline
\end{tabular}

Source: Cbn Statistical Bulletin And National Bureau of Statistics

\section{Appendix II}

Sustainable Development Goals

S/N GOALS

1 Poverty

2 Hunger

3 Health all ages

4 Education

$5 \quad$ Gender Equality and girls

6 Water

$7 \quad$ Sustainable Energy

8 Sustainable Economy economic growth,

9 Sustainable Industrialization and sustainable

10 Reduce Inequalities-

11 Inclusive Cities

12 Sustainable Consumption and ProductionEnsure sustainable consumption and production patterns

13 Urgent Action on Climate Change Take urgent action to combat climate change and its impact
End Poverty in all its form everywhere End Hunger, achieve food security and improved nutrition and promote sustainable agriculture

Ensure inclusive and equitable quality education and promote lifelong learning opportunities for all

Achieve gender equality and empower all women

Ensure availability and sustainable management of water and sanitation for all

Ensure access to affordable, reliable and sustainable andmodern energy for all

Promote sustained, inclusive and sustainable

full and productive employment and decent work for all

Build resilient infrastructure, promote inclusive industrialization and foster innovation Reduce inequality within and among countries Make cities and human settlements inclusive, safe, resilient and sustainable

\section{TARGET}

Ensure healthy lives and promote well-being for 
International Journal of Business Management and Economic Review

Vol. 4, No. 06; 2021

ISSN: 2581-4664

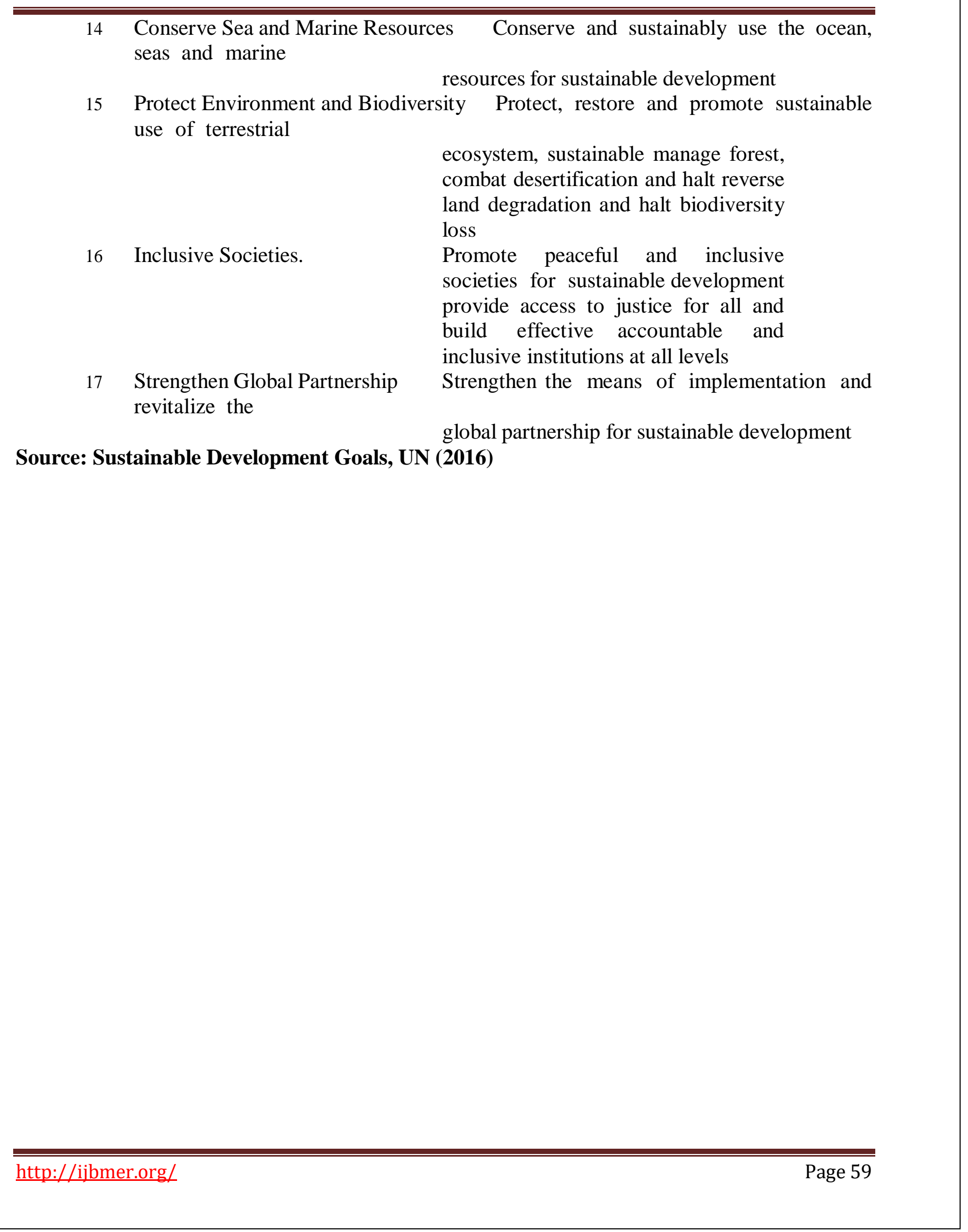

